\title{
The Implementation Of Spiritual Capital Saab Mote Craftsmen: Study Of The Hindu Teachings (Study Of Saab Mote Craftsman In Nagasepaha Village, Buleleng)
}

\section{Ni Wayan Novi Budiasni ${ }^{1 *}$, Ni Made Sri Ayuni ${ }^{2}$, Ni Kadek Ayu Trisnadewi ${ }^{3}$}

1,2,3STIE Satya Dharma Singaraja

\section{A R T I C L E I N F O}

Article history:

Received 19 May 2019

Received in revised form

16 June 2019

Accepted 15 July 2019

Available online 29 August

2019

Keywords:

Spiritual capital,

ethics (moral),

virtue (dharma),

harmony

(Tri Hita Karana ),

sustainability

\section{A B S T R A C T}

This study focused on implementing spiritual capital in the business of beads in Nagasepaha Village, Buleleng, which was studied using the concept of understanding the values of the teachings of Hinduism ethics (moral), harmony (Tri Hita Karana), virtue (dharma) Qualitative methods of gathering Observations, interviews and documentation data were carried out to obtain results and answer the research problem formulation. The concept of Tri Hita Karana that does not neglect harmony, is that the implementation of spiritual capital in the business of the most basic implicit. Merely and is not concerned with the material (capitalism), the which shows that there is ethics (moral), so as to create dharma (virtue) the which is the result of spiritual capital.

\footnotetext{
* Corresponding author.

E-mail addresses: ‥budiasni@gmail.com (Ni Wayan Novi Budiasni)
} 


\section{Introduction}

Economic growth is the result of the synergy of two types of resources, namely human resources and natural resources. This statement is found in the book W. Arthur Lewis entitled "Theory of Economic Growth (1972) . Of course, this view is trusted by business actors. However, on the other hand the view forget one aspect of divinity which is also important. A similar thing is conveyed by Gorda in Windia and Ratna (2007), who stated that Lewis's view ignored the Divine (God) resource element. This reflects secular-materialistic thinking, which ignores God's role in economic development. Resources in the economy, especially in accounting science are categorized as venture capital.

As we know, capital, or capital in accounting sciences is a resources in the form of money or goods material owned by the company. This definition leads to understanding capitalism that always related to money and material wealth. Spirit capitalism raises greed, greed, selfishness materialistic, prioritizing selfinterest, and opportunistic on human self when fielding self in business organizations (Mohammad, 2013). Triyuwono (2012) states that, accounting has been obsessed with material aspects and ignores nonmaterial aspects, as well as accounting symbols (accounts) that are still trapped in material symbols.

Based on the explanation, it can be said that accounting is generally more materialistic and tends to ignore spiritual values even though humans as accounting agents have two important things, material and spiritual. Sabam (2018), stated that this condition implies the application of universal law in the mainstream economy (including accounting) has the strong potential to suppress the values of local (local wisdom) prevailing in society. On the other hand, the existence of this partial nature gave birth to a culture of society that ignored ethical values, morality and social diversity as well as religious spirituality.

Situations that overly prioritize material aspects in accounting really need to be balanced with nonmaterial aspects. Now a concept of spiritual capital has developed which should not be ignored in accounting science. Bourdieu (1980) in Antonius (2011: 16) asserts that spiritual capital is the strength, influence, knowledge and circumstances created when there is participation in certain religious or religious traditions. A similar opinion on spiritual capital was also conveyed by Sabam (2018), who stated that accounting that applies spiritual capital is able to make accounting practices that encourage human behaviour more religious, have spiritual and ethical values in their social life and environment. The views expressed by Sabam increasingly emphasize that, it is very necessary to have a spiritual capital in a business organization, especially in the field of accounting.

Apart from the business organization with its capitalism flow, in Buleleng Regency, Bali there is a village that is Nagasepaha Village whose community mostly maintains its business in the modern era. Income from business of $s a a b$ beads cannot be made in main income, given the number of non-potential sales. Apart from that, the majority of the craftsmen of this restaurant are housewives. In the midst of the crush of increasingly complex economic needs, the craftsmen in the village in Nagasepaha village were still able to maintain their business. That condition illustrates that, mote business is not solely intended to seek maximum profit, should air flow capitalist business organizations. This phenomenon provides motivation for researchers to carry out further research on the field of business of saab mote craftsmen in Nagasepaha Village regarding spiritual capital that is not owned by capitalist business organizations. Considering that all craftsmen adhere to the teachings of Hinduism and students who are made by craftsmen as a means of worshiping Hindus, the spiritual capital in this study will be emphasized in the teachings of Hinduism.

Liu (2007) states spiritual capital refers to the strength, influence, and the circumstances created by the confidence, knowledge and practice spiritually from someone or an organization. A similar definition is also conveyed by Antonius (2011) who states that spiritual capital is capital which consists of encouragement, enthusiasm, and life in human beings. Based on the statement, it can be concluded that spiritual capital leads to spiritual aspects as capital in running a business or business organization.

The definition and presentation presented above are definitions and statements that generally lead to a belief. Furthermore, if studied according to the teachings of the Hinduism, spirituality is intellectual piety, aimed at seeking freedom ( $\underline{m o k s a}$ ) for individuals, usually with the guidance of a teacher ( Michaels, 2004). In addition, Wardana (2006) states, there are several spiritual values according to Hindu beliefs, including justice, timeliness, discipline, honesty, openness and sincerity. Furthermore, according to Sabam (2018), spirituality in the field of work, spirituality is doing work as a form of service. Being one thing that must be underlined that "effort" to achieve goals is the most important thing while "the results" are fully left to God. So, the view of Hindus regarding a business or business is more inclined to the sincerity run a job, not in a hurry to the results or benefits like the flow of capitalism. This view is in accordance with the teachings of Hinduism, namely morality. Susila (ethics) is formed from a set of behavioural values and norms that are directly or indirectly derived from the teachings of religion (Hinduism). Ethics ( moral) is closely related to the spiritual values of a person or group of people that are 
related to good and bad, right (Gorda, 2004). So spiritual capital of its closely related with the spiritual resources that is ethical (moral) in running the business. In the absence of ethics (moral), it is possible for a business not to be able to run well or knit.

Economic development that triggers the materialistic nature of society is a negative impact on the environment. It is still fresh in the memory of the Lapindo mud tragedy in Sidoarjo Regency which is still a problem and there seems to be no interested parties to resolve the problem. Losses that arise not only in the form of material and soul, but also in the form of " heritage ". The Lapindo case successfully destroyed a social community (community). But now, society tries to return to the spiritual-religious dimension to fill its spiritual void and give meaning to its life. This condition indicates that the community is not satisfied with economic abundance alone. Conversely a more meaningful life is disciplined with a moral foundation, ethics and spiritual-religious become new needs (Gorda, 2004: 38).

Similar conditions also occur in the application of accounting science. The application of modern accounting tends to produce unsatisfactory effects. The facts show the many accounting scandals and manipulation of financial statements that hit the company as well as the lack of concern for social and environmental responsibility (Sabam, 2018). Francis (1990) in Gaffikin (2008: 184), also argues that " worship of money ", lately has influenced many accounting practices and concluded that if accounting is indeed a "virtue", accounting should proclaim that accounting is the result human creation and is the moral "agent" itself. Similar opinions were also expressed by Suryaningrum ( 2011 ), who stated that social accounting is now beginning to develop due to concerns about corporate ethics, corporate power, and declining environmental ecology. Zohar and Marshall (2005), explain the spiritual aspects in terms of spiritual capital which is an increased capital by utilizing resources that are in one's self or soul so that later it will give birth to the intelligence of conscience. Spiritual capital explained is a high spirit to achieve victory that grows in a person. With that enthusiasm, it will give birth to a love of work, a high work ethic, a soul to help each other, respect for others so that it creates a harmonious environment in the workplace. Spiritual capital is seen as the beginning of awareness in many business related thoughts that spirituality is very important and has an influence on business as other capital. Based on the explanation, it can be said that spiritual capital is closely related to moral resources and behaviour based on norms that exist in humans.

\section{Methods}

This research was conducted using qualitative methods. Qualitative methods Qualitative research is a research method based on the philosophy of post positivism, used to examine the condition of natural objects, (as opposed to experiments) where the researcher is a key instrument, the technique of data collection is triangulated (combined), analysis of data is inductive / qualitative, and the results of qualitative research emphasize more meaning than generalization (Sugiyono, 2013).

This method was used because the purpose of this study was that it tended to look for meaning related to spiritual capital in mote craftsmen in Nagasepaha Village. Quantitative data in the form of the income of craftsmen and qualitative data in the form of interviews were used in this study. The source of primary data comes from the results of interviews and secondary in the form of literature studies up to general description of Nagasepaha Village. Triangulation techniques are used to obtain the same data using different techniques (Sugiyono, 2013). The data collection techniques are done by using the method of documentation, observation, and interviews.

Research informants were purposively appointed. The appointment was purposive because it considered the informants' understanding of the problem under study. As for the informants in this study were 5 craftsmen or friends. These 5 craftsmen were chosen, because they were based on information, these five craftsmen were the most consistent in running the business. The informants include :

Table 1. Research Informant

\begin{tabular}{lll}
\hline No & Name of Chaftsman & Product \\
\hline 1 & Ni Ketut Kocap & Saab mote, mote wall hangings \\
& & Lamak mote, nare mote, and \\
& & tamiang mote \\
2 & Ni Ketut Seni & Saab mote \\
3 & Ni Komang Nadi & Saab mote \\
4 & Ni Nyoman Yasni & Saab mote, lamak mote, tamiang \\
& & mote, and nare mote \\
5 & Ni Ketut Mantening & Saab mote \\
\hline
\end{tabular}


Data analysis is done to organize data, describe it into units, synthesize, arrange into patterns, choose which ones are important and which will be studied, and make conclusions that can be told to others (Sugiyono, 2013). To analyse the data, researchers used Miles and Hubberman's Interactive Data Analysis.

\section{Result and Discussion}

The fruit of this spiritual capital is "virtue". One of the most influential virtues in business is faith (a sense of trust that when he does well, his business will benefit) (Lutfi, 2017). In addition, Nuryani (2018) states that spiritual values in everyday life are interpreted as spiritual life, namely the phenomenon of life that is based on the highest and deepest corporate goals. So that spiritual values that surround the company, become a powerful fortress in the continuation of the company.

As explained above, the fruit of this spiritual capital is "virtue". The teachings of Hinduism recognize virtue with the term dharma. Dharma is a human goal to realize the atmosphere of life in a world that is safe, peaceful and peaceful. This can be realized if someone lives and practices the teachings, values, norms that come from religious teachings expressed in the Vedic sacred literature (Gorda, 2004). The sloka passage is in Rigveda.I.41.4 which reads:

"Someone who works based on dharma, never encounters obstacles in the course of his life and everything becomes easy"

And Rgveda.X.107.2 reads:

"People who always do according to dharma will get peace of life"

The sloka excerpt was in rhythm with the revelation delivered by the craftsman in the village in Nagasepaha Village. The craftsmen are diligent creating mote and sincere in their efforts. The business they live is based on pleasure, not solely based on economic motives. With sincerity, wholeheartedness, and perseverance (passion) possessed by craftsmen or mote, undoubtedly virtue will be created. In accordance with this statement, of course the saab mote craftsmen in the Village of Nagasepaha have a spiritual capital in carrying out business yes. Besides that, despite the low income, amidst increasingly complex needs, they can still make the business easier as a family economic driver. Of course the efforts carried out do not deviate from the values and norms of behaviour (ethics, morality), because the craftsmen have the spirit to perfect work continuously based on the values believed (dharma) (Gorda, 2004).

The definition of capital still dwells on material wealth. This fact makes business people increasingly put aside the values of spirituality in life making them have separate personalities (split personalities) (Khairi, 2013). Therefore, this study focuses on giving awareness of the importance of spiritual capital based on the values of Religion Hinduism, spiritual capital in this study is seen from a Hindu perspective so that it is not the same as spiritual capital which demands the universality of values in it. Windia \& Ratna (2007), recommending the concept of Tri Hita Karana earthed (applied) in spiritual discipline (sadana) and love and devotion, it will create an ethical entrepreneurial spirit towards true success in managing a business. Overview of the concept of Tri Hita Karana teaches that human beings live a harmonious life in three elements, namely parhyangan (harmonious relationship between man and God Almighty), pawongan (harmonious relationship between human beings), and palemahan (harmonious relationship between humans and the environment).

If it is related to the business of craftsmen in the village of Nagasepaha, based on the results of the information the researchers collected, the craftsmen or mote did not let go of the concept of Tri Hita Karana in carrying out their business. First from the parhyangan aspect, saab mote is a means of ceremony (yadnya) of Hindus to Ida Sang Hyang Widhi Wasa, so indirectly dedicating his life to worship. Second, the aspect of pawongan is reflected in the collaboration between craftsmen. For example, what was done by Ms. Ni Ketut Kocap who helped the surrounding mothers who had limited capital to help her make a skeleton or mote. The business behaviour reflects that Ni Ketut Kocap has concern with others around him. Craftsmen besides Ni Ketut Kocap also carry out the same method in carrying out their business. Then the palemahan aspect, the type of business that is run by the craftsmen is a business with the main ingredients that are environmentally friendly and utilizing unused cardboard remains to be more valuable. The main ingredient in making saab mote is the leaves of sugar palm trees (ental leaves) which are dried, then reinforced again with cardboard, before finally being pinched and decorated with mote.

The above explanation is in accordance with the definition of spiritual capital according to Bourdieu (1980) in Antonius (2011), which emphasizes that spiritual capital is a branch of social capital . And spiritual capital is the strength, influence, knowledge, and circumstances created by participation in 
certain religious traditions. Bourdieu also explained that social capital is closely related to cultural capital, economic capital (natural resources and wealth), and symbolic capital (social status) which is capital that encourages someone to excel. All of these capital are encouraged and encouraged by spiritual capital that emerges in and from religious capital (the strength of certain religious teachings and traditions) that makes people motivated to do good to society. The creation of a good relationship with the surrounding environment (community) will be one of the supporters of the smooth running of a business.

\section{Conclusion}

The craftsman in the village of Nagasepaha certainly must have applied spiritual capital. This is known through the motive of running a business not only limited to the economy, and running it sincerely based on pleasure. The craftsmen also uphold the application of the concept of Tri Hita Karana as a builder of harmony in the operations, which is strengthened with ethics (moral). By being based on harmony, morals, ethics, which makes the business they live in quite ethical in the business world. Based on the firmness in the Tri Hita Karana concept and ethics (moral), of course, it will create virtue or dharma which is the result of spiritual capital. So we can be sure that the craftsmen in the village of Nagasepaha have implemented spiritual capital well.

Suggestions that can be conveyed are related to other larger businesses, businesses that are as large as households with capital are not how hard they are to uphold the values of God in their operations. A big effort should be ashamed to over exploit the resources of his creation but not remember his obligation to give thanks for his gifts.

This research is still limited to studying spiritual capital from the perspective of Hindu Teachings and from case study findings obtained by the basis of spiritual capital in the organization that is a business that is still guided by virtue (dharma) through ethics (morality) and aspects of harmony (Tri Hita Karana). Thus other studies can explore spiritual capital from the values of other Hindu teachings. In addition, this study has not studied universal spiritual capital. This research is still limited to understand the concepts and have not done the measurement and presentation of spiritual capital as the financial capital

\section{Reference}

Antonius, Bele.2011.” Nurani Suku Buna Spiritual Capital dalam Pembangunan “. Desertasi. Universitas Kristen Satya Wacana. Salatiga.

Gaffikin, Michael. 2008. "Accounting theory: Research, regulation, and accounting practice,Pearson Education, Australia".

Gorda, I Gusti Ngurah.2004."Membudayakan Kerja Berdasarkan Dharma".Pusat Kajian Hindu, Budaya, dan Perilaku Organisasi. Sekolah Tinggi Ilmu Ekonomi Satya Dharma Singaraja.

Khairi, Mohammad Shadiq. 2013. Memahami Spiritual Capital dalam Organisasi Bisnis Melalui Perspektif Islam. Universitas Brawijaya : Jurnal Akuntansi Multiparadigma JAMAL Volume 4 Nomor 2,Halaman.165-329.

Liu, Alex. 2007. "Measuring Spiritual Capital as a Latent Variable”, The Research Methods Institute.

Luthfi, Muhammad.2017."Analisis Pengaruh Spiritual Capital terhadap Kinerja Karyawan serta Dampaknya pada Keunggulan Bersaing (Studi Kasus pada Komplek Bidakara PT. Mekar Prana Indah)". Skripsi. Program Studi Manajemen, UNIVERSITAS ISLAM NEGERI SYARIF HIDAYATULLAH-Jakarta.

Michaels, Axel .2004." Hinduism". Past and present, Princeton, New Jersey: Princeton University Press.

Sabam P Munthe, Andre. 2018. Akuntansi Spiritual. Diakses di : https://id.scribd.com , pada tanggal 15 April 2019 .

Sugiyono.2013. "Metodelogi Penelitian Kuantitatif Kualitatif dan R\&D. Penerbit : Alfabeta, Bandung. 